\title{
Changes in the immunoreactivity of follistatin within preovulatory follicles after the primary gonadotrophin surge in rats
}

\author{
K. Ogawa ${ }^{\mathrm{I}}$, M. Kurohmaru ${ }^{\mathrm{I}}, \mathrm{H}$. Sugino $^{2}$ and $\mathrm{Y}$. Hayashi $^{\mathrm{I}}$ \\ ${ }^{1}$ Department of Veterinary Anatomy, Faculty of Agriculture, The University of Tokyo, Bunkyo-ku, \\ Tokyo, 113 Japan; and ${ }^{2}$ Frontier Research Program. The Institute of Physical and Chemical Research \\ (RIKEN), Wako, Saitama, 351-01 Japan
}

\begin{abstract}
Cyclic changes in follistatin localization and the role of the primary gonadotrophin surge in regulating follistatin expression were studied in rat ovaries by immunohistochemistry. Two different polyclonal antisera were raised against synthetic peptides corresponding to amino acids 123-134 and 300-315 of human follistatin. Immunoreactive follistatin was detected in granulosa cells of secondary and mature follicles. Although immunoreactions with antifollistatin (300-315) occurred in preovulatory follicles until immediately before ovulation (23:00 $\mathrm{h}$ on the day of pro-oestrus), follistatin was not immunodetected in newly formed corpora lutea (11:00 h on the day of oestrus). Granule-like immunoreactions with antifollistatin (123-134) serum in preovulatory follicles markedly decreased in intensity on the evening of pro-oestrus, indicating the loss of follistatin production. Blocking the primary gonadotrophin surge by a pentobarbitone injection $\left(40 \mathrm{mg} \mathrm{kg}^{-1}\right)$ at $13: 30 \mathrm{~h}$ on the day of pro-oestrus sustained the immunoreactivity with anti-follistatin (123-134) in preovulatory follicles up to $23: 00 \mathrm{~h}$ on the day of pro-oestrus. Injection of pentobarbitone-treated animals with exogenous $\mathrm{LH}\left(100 \mu \mathrm{g} \mathrm{kg}^{-1}\right)$ or FSH $\left(50 \mu \mathrm{g} \mathrm{kg}^{-1}\right)$ at $15: 30 \mathrm{~h}$ on the day of pro-oestrus eliminated the immunoreactions. These results indicate that the expression of follistatin in preovulatory follicles is suppressed by the primary gonadotrophin surge during pro-oestrus. Hence, it is conceivable that the cessation of follistatin production in preovulatory follicles may occur before ovulation, and that it may be caused by the primary gonadotrophin surge.
\end{abstract}

\section{Introduction}

Activin was initially isolated from gonads as a stimulator of FSH secretion. It was found to be a dimer of the $\beta$ subunit of inhibin, which is an inhibitor of FSH secretion (Vale et al., 1986; Esch et al., 1987; De Jong, 1988; Schwall et al., 1988). Follistatin, originally obtained from pig follicular fluid during the isolation of inhibin and activin, is structurally different from inhibin and activin in spite of its inhibin-like activity (Ueno $e t$ al., 1987; Shimasaki et al., 1988a). It was thought that activin and follistatin from the gonads modulate FSH release in a long-loop feedback manner to the pituitary. However, their broad distribution throughout the body, including the pituitary gland (Gospodarowicz and Lau, 1989; Kogawa et al,. 1991), suggests that they act in a paracrine manner.

Nakamura et al. (1990) found that follistatin is an activinbinding protein. Follistatin binds to both inhibin and activin through the common $\beta$ subunit (Shimonaka et al, 1991). Neutralization of activin activity by follistatin has been observed in various systems, such as in the stimulation of FSH secretion in cultured pituitary cells (Kogawa et al., 1991), induction of mesoderm tissue formation in Xenopus oocytes (Asashima et al., 1991), and differentiation of rat granulosa cells
(Nakamura et al., 1991). These results suggest that follistatin is a functional regulator of the activity of activin.

Several investigations have been carried out on the actions of inhibin and activin in the ovary (Tsafriri et al., 1989; Woodruff et al., 1990; Xiao et al., 1990). Recent evidence suggests that inhibin and activin regulate follicular maturation in a paracrine manner (Woodruff et al., 1990; Doi et al., 1991). Follistatin may therefore have a significant role in follicular development as a functional regulator of inhibin and activin. Furthermore, inhibin and activin are potential modulators of oocyte maturation in rats (O et al., 1989; Itoh et al., 1990). Thus, follistatin is thought to be important in oocyte maturation in vivo. To clarify the role of follistatin and its mechanism of regulation of inhibin and activin activity during folliculogenesis and oogenesis, we investigated the cyclic changes in immunoreactive follistatin in rat ovaries by immunohistochemistry using antisera raised against synthetic peptides corresponding to two different regions of human follistatin.

\section{Materials and Methods}

\section{Animals and treatments}

Female Wistar Imamichi rats were obtained from the Imamichi Institute for Animal Reproduction (Ibaraki). All 
animals were maintained in air-conditioned quarters on a photoperiod of $14 \mathrm{~h}$ light: $10 \mathrm{~h}$ dark (lights on at 05:00 h) and were given food and water ad libitum.

Immunohistochemical changes during the oestrous cycle were examined by excising the ovaries from adult rats (8-12 weeks old) at 11:00 h on the days of dioestrus I, dioestrus II, pro-oestrus and oestrus. These stages were estimated by the appearance of vaginal smears. Four animals were used for each experimental group.

The effects of the gonadotrophin surge on immunoreactive follistatin in the ovary were determined by examining rats at pro-oestrus. They were divided into four experimental groups: group I was untreated; group 2 was treated with pentobarbitone alone; group 3 received pentobarbitone plus $\mathrm{LH}$; and group 4 was treated with pentobarbitone plus FSH. Each group consisted of four animals. Groups 2, 3 and 4 received an injection of $40 \mathrm{mg}$ pentobarbitone $\mathrm{kg}^{-1}$ i.p. at 13:30 h on the day of pro-oestrus. At $15: 30 \mathrm{~h}$ on the day of pro-oestrus, rats in group 3 were injected i.v. with $100 \mu \mathrm{g} \mathrm{LH} \mathrm{kg}^{-1}$ dissolved in $0.25 \mathrm{ml}$ of sterile saline, and rats in group 4 were injected with $50 \mu \mathrm{g} \mathrm{FSH} \mathrm{kg} \mathrm{kg}^{-1}$ in $0.25 \mathrm{ml}$ of sterile saline. Ovine $\mathrm{LH}$ (NIADDK-oLH-26) and FSH (NIADDK-oFSH-17) were provided by the National Institute of Diabetes and Kidney Disease (NIDDK, Baltimore, MD). The animals were killed at 23:00 $\mathrm{h}$ on the day of pro-oestrus to excise ovaries for immunohistochemical examination.

\section{Preparation of tissue sections}

Tissues excised from animals were fixed in Bouin's fixative in a microwave oven for $20 \mathrm{~s}$ at $4^{\circ} \mathrm{C}$ and then immersed in the same fixative for $4-6 \mathrm{~h}$ at room temperature. After fixation, the tissues were dehydrated in a graded ethanol series, cleared in xylene, and embedded in paraffin wax. On a sliding microtome, sections were cut to a thickness of $4 \mu \mathrm{m}$ and subjected to immunohistochemical procedures.

\section{Immunohistochemical procedure}

Two different rabbit polyclonal antisera against synthetic follistatin peptides corresponding to amino acids $123-134$ or 300-315 of human follistatin (Saito et al., 1991) were used in this study. These antisera were purified by affinity chromatography on protein-A-Sepharose before performing immunohistochemistry.

The procedure using avidin-biotin-peroxidase was performed as described by $\mathrm{Hsu}$ et al. (1981). After deparaffinizing, the sections were incubated in $3 \% \mathrm{H}_{2} \mathrm{O}_{2}$ in methanol for $30 \mathrm{~min}$ to eliminate endogenous peroxidase. They were placed in a moist chamber, covered with $5 \%$ normal goat serum for $30 \mathrm{~min}$ to minimize nonspecific staining, followed by rabbit antiserum diluted from $1: 100$ to $1: 1000$ with $0.3 \%$ BSA in $0.01 \mathrm{~mol} \mathrm{PBS} \mathrm{l}^{-1}$ for overnight incubation at room temperature. After washing with $0.01 \mathrm{~mol} P B S 1^{-1}$, they were incubated with biotinylated goat anti-rabbit immunoglobulin $G$ for $30 \mathrm{~min}$ and then with avidin-biotin-peroxidase (Vector Laboratories Inc., Burlingame, CA) for $45 \mathrm{~min}$. A mixture of $0.05 \% 3,3^{\prime}$-diaminobenzidine tetrahydrochloride in $0.01 \mathrm{~mol}$
PBS I ${ }^{-1}$ and $0.01 \% \mathrm{H}_{2} \mathrm{O}_{2}$ was added for 7-10 min to develop the peroxidase reaction.

The method and antiserum specificity were confirmed by incubating sections with either normal rabbit serum from the same rabbit from which the anti-follistatin serum had been obtained, or primary antiserum absorbed using an excess of the peptide and haemocyanin. Additional controls were stained without secondary antiserum or avidin-biotin-peroxidase.

\section{Results}

Different staining patterns of ovaries using two follistatin antisera

Luteal and theca cells did not react with follistatin antisera throughout the stages examined in this study. The oocytes in follicles from the primordial to the mature stage were also negative for both antisera. However, in granulosa cells positive reactions with the antisera were shown in follicles from the secondary to the mature stage, whereas no reaction was observed in primordial and primary follicles. The cytoplasm of granulosa cells in secondary follicles exhibited granule-like reactions with anti-follistatin (123-134) and diffuse reactions with anti-follistatin (300-315). Reactions with both antifollistatin (123-134) and anti-follistatin (300-315) were more intense in larger follicles. This differential staining pattern in the cytoplasm of granulosa cells was also observed in mature follicles, that is, the granule-like reaction with anti-follistatin (123-134) (Fig. 1a) and the diffuse reaction with anti-follistatin (300-315) (Fig. 1b). Conversely, neither anti-follistatin (123134) nor anti-follistatin (300-315) exhibited a positive reaction in the granulosa cells of atretic follicles.

\section{Changes in the immunostaining pattern of follistatin in preovulatory follicles}

Although the intense granule-like reaction with antifollistatin (123-134) was detected in the cytoplasm of granulosa and cumulus cells from the day of dioestrus to $11: 00 \mathrm{~h}$ on the day of pro-oestrus (Fig. 2a), the reaction was absent by 23:00 h on the day of pro-oestrus (group 1) after cumulus expansion had occurred in the follicle (Fig. 2b). In contrast to the reactions with anti-follistatin (123-134), the diffuse reactions with anti-follistatin (300-315) persisted in the cytoplasm of granulosa and cumulus cells throughout the oestrous cycle (Fig. 2c, d). Oocytes were not stained with any antisera throughout the oestrous stages examined. At 11:00 h on the day of oestrus no reactions were detected in newly formed corpora lutea with any antisera.

\section{Effect of blocking the gonadotrophin surge and subsequent} replacement with exogenous gonadotrophin on follistatin expression in preovulatory follicles

As described above, immunoreactions with anti-follistatin (123-134) were not found in preovulatory follicles in untreated animals at 23:00 h on the day of pro-oestrus (group 1) (Table 1). Blocking the primary gonadotrophin surge by injection of pentobarbitone sustained anti-follistatin (123-134) reactions in 

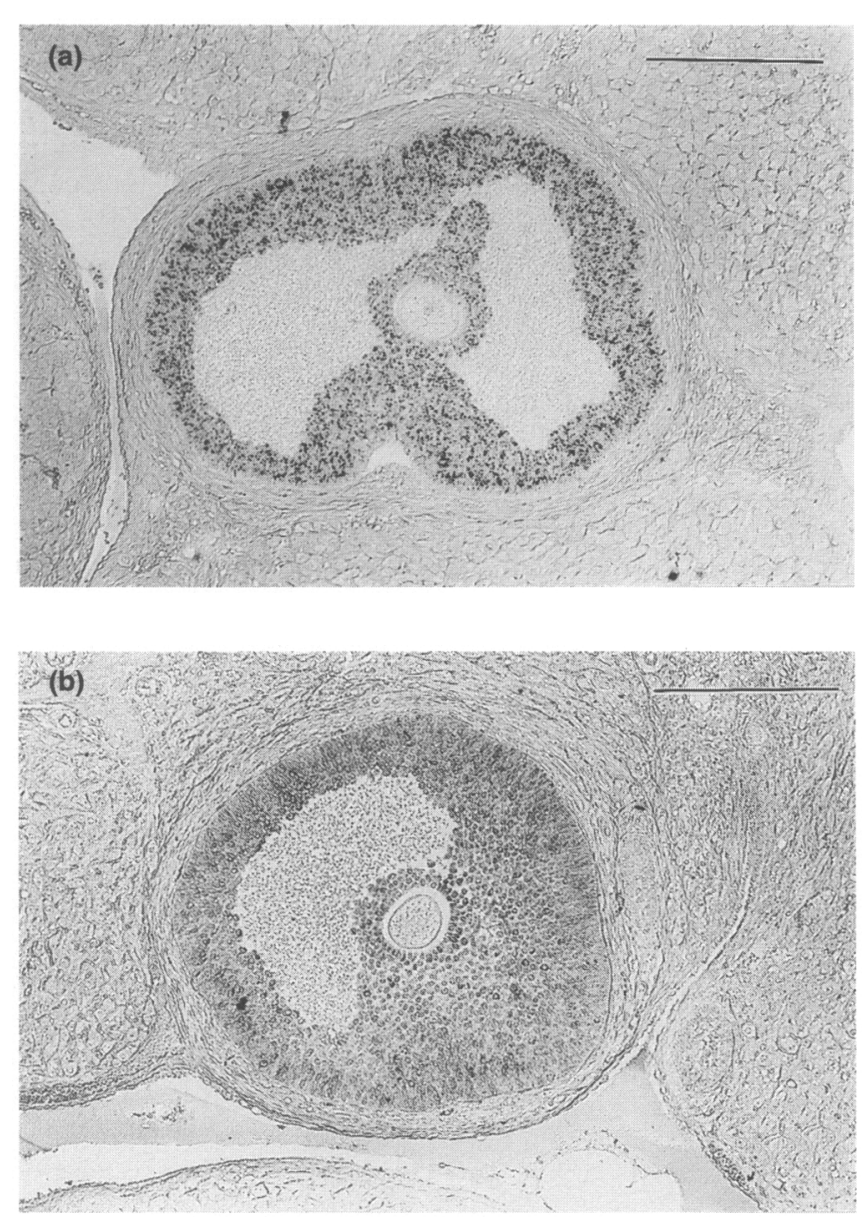

Fig. 1. Photomicrographs showing localization of immunoreactive follistatin using two different antisera against follistatin peptides in rat ovaries. (a) Immunoreactions with anti-follistatin (123-134) are granule-like in granulosa cells of mature follicles at dioestrus I. (b) Reactions with anti-follistatin $(300-315)$ are diffuse in these cells. Scale bar represents $100 \mu \mathrm{m}$.

preovulatory follicles (group 2). Subsequent treatment of pentobarbitone-treated animals with LH or FSH (group 3 or group 4, respectively) markedly decreased granule-like reactions with anti-follistatin (123-134) at $23: 00 \mathrm{~h}$ as it did in intact animals (group 1). Reactions with anti-follistatin (300-315) in preovulatory follicles were intense in all groups except at 23:00 $\mathrm{h}$ on the day of pro-oestrus in the granulosa cells, when reactions were mainly moderate.

\section{Discussion}

We demonstrated changes in follistatin localization within rat ovaries using two different antisera. In the present study, immunoreactive follistatin was not detected in either luteal or theca cells but was found in ganulosa cells. These results support the previous finding that granulosa cells are the source of follistatin (Shimasaki ef al., 1989). The present study indicates that follistatin is more abundant in mature follicles than in immature follicles. This finding supports a previous study in which follistatin mRNA and the protein were not detected in primordial and primary follicles but were found in secondary and mature follicles (Nakatani et al., 1991).

Although granulosa cells were intensely stained with both anti-follistatin (123-134) and (300-315) antisera, the staining patterns were remarkably different between the two antisera, that is, granule-like with anti-follistatin (123-134) and diffuse with anti-follistatin (300-315). Structure analysis of the gene encoding follistatin in humans (Shimasaki et al, 1988a), pigs (Shimasaki et al., 1988b) and rats (Michel et al., 1990) revealed the existence of two forms of follistatin, the long form (residues I-315) and the short form (residues 1-288). Anti-follistatin (300-315) was raised against the peptide corresponding to the 16 amino acids at the carboxy-terminal end of follistatin, which means that this antiserum detects only the long form of follistatin; anti-follistatin (123-134) detects both the short and long forms of follistatin in SDS-PAGE and immunoblotting (Saito et al., 1991).

It is unclear why the reaction with anti-follistatin (123-134) was not observed, while that with anti-follistatin (300-315) persisted in preovulatory follicles on the evening of prooestrus. At least three types of follistatin with different molecular masses $(32,35$ and $39 \mathrm{kDa})$ are present in the follicular fluid (Esch et al., 1987; Robertson et al., 1987; Ueno et al., 1987; Shimasaki et al., 1988b), suggesting that the conformation of the follistatin molecule is altered according to glycosylation. Six molecular species of follistatin created by carboxy-terminal truncation or the presence of carbohydrate chains have been purified from pig ovaries (Sugino et al., 1993). Moreover, the molecular conformation of follistatin may be altered on binding with inhibin or activin. It is conceivable that the difference in reactivity between the two antisera may be caused not only by the presence or absence of the carboxyterminal sequence of follistatin, but also by the difference in the molecular conformation of follistatins that are stained by each antiserum.

In our results, although the granule-like reaction with anti-follistatin (123-134) was detected in preovulatory follicles from oestrus to $11: 00 \mathrm{~h}$ on the day of pro-oestrus, the reaction was not seen at $23: 00 \mathrm{~h}$ on the day of pro-oestrus. Follistatin was not detected in newly formed corpora lutea (11:00 h on the day of oestrus), while immunoreactions with anti-follistatin (300-315) persisted in preovulatory follicles until $23: 00 \mathrm{~h}$ on the day of pro-oestrus. These results are in agreement with an in situ hybridization study (Shimasaki et al., 1989), which revealed that the amount of mRNA in smaller follicles was higher than that in larger preovulatory follicles, and that very little follistatin mRNA was present in some corpora lutea in 35-day-old rats $24 \mathrm{~h}$ after injection of 50 iu of pregnant mares' serum gonadotrophin (Shimasaki et al., 1989).

It is suggested that the cessation of follistatin production may occur on the evening of pro-oestrus. However, a previous study on cyclic changes in follistatin expression in the rat ovary showed that mRNA signals and immunohistochemical signals were found in follicles from the preovulatory stage (10:00 h on the day of pro-oestrus) to the newly formed corpora lutea stage (10:00 h on the day of oestrus) (Nakatani et al., 1991). Furthermore, Mercado et al. (1993) showed that the amount of follistatin mRNA in the ovary increases between pro-oestrus and oestrus. One possible explanation for this inconsistency in results is that the molecular conformation of 

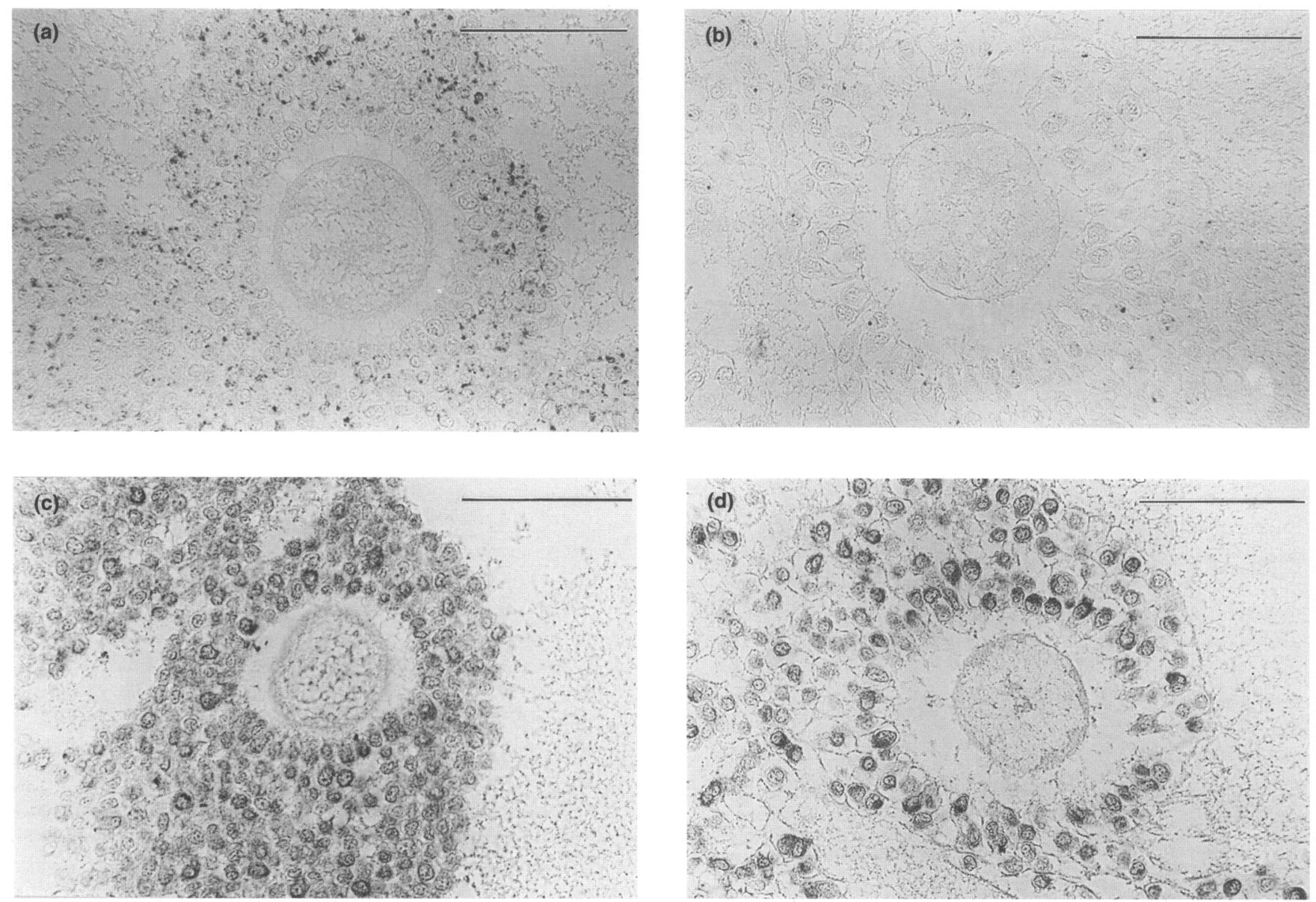

Fig. 2. Changes in the immunostaining pattern of two anti-follistatin antisera in granulosa and cumulus cells in rat ovaries immediately before ovulation. (a) Intense granule-like reactions with anti-follistatin (123-134) are found in granulosa cells until 11:00 h on the day of pro-oestrus. (b) By 23:00 h on the day of pro-oestrus, the immunoreactions have disappeared except for a few remaining in cumulus cells. (c) Diffuse reactions occur with anti-follistatin $(300-315)$ at $11: 00 \mathrm{~h}$ on the day of pro-oestrus. (d) Reactions with anti-follistatin (300-315) are still observed immediately before ovulation (at 23:00 h on the day of pro-oestrus). Scale bar represents $50 \mu \mathrm{m}$.

Table 1. Effect of blocking the gonadotrophin surge and subsequent replacement with exogenous gonadotrophin on the expression of immunoreactive follistatin in preovulatory follicles in rats

$\begin{array}{cccr}\text { Control } & \begin{array}{c}\text { Pentobarbitone } \\ \left(40 \mathrm{mg} \mathrm{kg}^{-1}\right)^{\mathrm{a}}\end{array} & \begin{array}{c}\text { Pentobarbitone } \\ \left(40 \mathrm{mg} \mathrm{kg}{ }^{-1}\right)+\mathrm{LH}\left(100 \mu \mathrm{kg}^{-1}\right)^{\mathrm{b}}\end{array} & \begin{array}{c}\text { Pentobarbito } \\ \left(40 \mathrm{mg} \mathrm{kg}^{-1}\right)+\mathrm{FSH}\end{array} \\ - & +++ & - & - \\ ++ & +++ & ++ & ++ \\ & & & \\ \pm & +++ & + & \pm \\ +++ & +++ & ++ & +++\end{array}$

Intensity of reaction: - , negative; + , weak; ++ , moderate; +++ , intense.

${ }^{2}$ Treatment administered at 13:00 $\mathrm{h}$ at pro-oestrus.

${ }^{\mathrm{b}}$ Treatment with pentobarbitone administered at $13: 00 \mathrm{~h}$ and $\mathrm{LH}$ or $\mathrm{FSH}$ at $15: 30 \mathrm{~h}$ at pro-oestrus.

follistatin in preovulatory follicles changes on the evening of pro-oestrus. Such divergent results with two antisera directed against different epitopes indicate modification of the follistatin molecule. Follistatin in preovulatory follicles may alter their conformation to conceal the $123-134$ and then the 300-315 amino acid region before luteal formation, while at the same time revealing the epitope that was recognized by the antiserum used by Nakatani et al. (1991). 
Blocking the primary gonadotrophin surge by pentobarbitone injection sustained the follistatin reactions with anti-follistatin (123-134) in mature follicles at $23: 00 \mathrm{~h}$ on the day of pro-oestrus. After injecting the pentobarbitone-treated animals with exogenous LH or FSH, the reactions with anti-follistatin (123-134) ceased. These results indicate that the changes in follistatin immunoreactivity in preovulatory follicles are induced by the primary gonadotrophin surge during pro-oestrus.

The absence of anti-follistatin (123-134) reactions in preovulatory follicles was synchronized with cumulus expansion. At the time of cumulus cell expansion, germinal vesicle breakdown occurs in oocytes in preovulatory follicles. A previous study suggested that inhibin inhibits oocyte maturation in rat oocytes (O et al., 1989). Furthermore, Itoh et al. (1990) showed that activin stimulates oocyte maturation not only in cumulus-enclosed oocytes but also in denuded oocytes. If inhibin and activin act on oocyte maturation in vivo, follistatin may also play an important role in oogenesis by regulating inhibin and activin activity.

However, it was also suggested that inhibin stimulates follicular maturation, while activin inhibits it (Woodruff et al., 1990). Nakatani et al. (1991) therefore postulated that follistatin plays a role in selecting and recruiting follicles to the ovulatory pool by suppressing the inhibitory activity of activin. However, Doi et al. (1991) reported that daily injections of activin s.c. caused a marked increase in ovarian mass and the development of large follicles. In addition to this discrepancy in results, it is unclear whether the sole physiological action of follistatin is to suppress the activity of activin. Further studies are required to clarify the physiological role of activin and its interaction with follistatin during oogenesis and folliculogenesis.

The authors thank the NIDDK for providing the ovine gonadotrophins used for replacement therapy, and the Imamichi Institute for Animal Reproduction (Ibaraki, Japan) for providing the animals used in this study. This work was supported in part by Grant in Aid for Scientific Research (No. 04454114) from the Ministry of Education, Science and Culture of Japan.

\section{References}

Asashima M, Nakano H, Uchiyama H, Sugino H, Nakamura T, Eto Y, Ejima D, Davids M, Plessow S, Cichoka I and Kinoshita K (1991) Follistatin inhibits the mesoderm-inducing activity of activin $\mathrm{A}$ and the vegitalizing factor from chicken embryo Roux's Archives of Developmental Biology 200 4-7

De Jong FH (1988) Inhibin Physiological Review 68 555-607

Doi M, Igarashi M, Hasegawa Y, Eto Y, Shibai H, Miura T and Ibuki Y (1991) In vivo action of activin-A on the pituitary-gonadal system Endocrinology $130 \quad 139-144$

Esch FS, Shimasaki S, Cooksey K, Mercado M, Mason AJ, Ying S-H, Ueno N and Ling $N$ (1987) Complementary deoxyribonucleic acid (cDNA) cloning and DNA sequence analysis of rat ovarian inhibin Molecular Endocrinology 1 388-396

Gospodarowicz D and Lau K (1989) Pituitary follicular cells secrete both vascular endothelial growth factor and follistatin Biochemical and Biophysical Research Communications 165 292-298

Hsu SM, Raine L and Fanger H (1981) Use of avidin-biotin-peroxidase complex $(A B C)$ in immunoperoxidase techniques Journal of Histochemistry and Cytochemistry 29557
Itoh M, Igarashi M, Yamada K, Hasegawa Y, Seki M, Eto Y and Shibai H (1990) Activin A stimulates meiotic maturation of the rat oocyte in vitro Biochemical and Biophysical Research Communications 166 1479-1484

Kogawa K, Nakamura N, Sugino K, Takio K, Titani K and Sugino H (1991) Activin-binding protein is present in pituitary Endocrinology 128 1434-1440

Mercado M, Shimasaki S, Ling N and DePaolo L (1993) Effect of estrous cycle stage and pregnancy on follistatin gene expression and immunoreactivity in rat reproductive tissues: progesterone is implicated in regulating uterine gene expression Endocrinology 132 1774-1781

Michel U, Albiston A and Findlay JK (1990) Rat follistatin: gonadal and extragonadal expression and evidence for alternative splicing Biochemical and Biophysical Research Communications 173 401-407

Nakamura T, Takio K, Eto Y, Shibai H, Titani K and Sugino H (1990) Activinbinding protein from rat ovary is follistatin Science 247 836-838

Nakamura T, Sugino K, Titani K and Sugino H (1991) Follistatin, an activinbinding protein, associates with heparan sulfate chain of proteoglycans on follicular granulosa cells Journal of Biological Chemistry 266 19432-19437

Nakatani A, Shimasaki S, Depaolo LV, Erickson GF and Ling N (1991) Cyclic changes in follistatin messenger ribonucleic acid and its protein in rat ovary during the estrous cycle Endocrinology 129 603-611

O W-S, Robertson DM, and de Krester DM (1989) Inhibin as an oocyte meiotic inhibitor Molecular and Cellular Endocrinology 62 307-311

Robertson DM, Klein R, de Vos FL, McLachlan RI, Wettenhall REH, Hearn MTW, Burger HG and de Krester DM (1987) The isolation of polypeptides with FSH suppressing activity from bovine follicular fluid which are structurally different to inhibin Biochemical and Biophysical Research Communications 149 $744-749$

Saito S, Sugino K, Yamanouchi K, Kogawa K, Titani K, Shiota K, Takahashi M and Sugino H (1991) Characterization of antisera directed against follistatin/ activin-binding protein peptides Endocrinologica Japonica 38 377-382

Schwall RH, Szonyi E, Mason AJ and Nikolics K (1988) Activin stimulates secretion of follicle-stimulating hormone from pituitary cells desensitized to gonadotropin-releasing hormone Biochemical and Biophysical Research Communications 151 1099-1104

Shimasaki S, Koga M, Esch F, Cooksey K, Mercado M, Koba A, Ueno N, Ying S-Y and Ling N (1988a) Primary structure of the human follistatin precursor and its genomic organization Proceedings of the National Academy of Sciences USA 85 4218-4222

Shimasaki S, Koga M, Esch F, Mercado M, Cooksey K, Koba A and Ling N (1988b) Porcine follistatin gene structure supports two forms of mature follistatin selectively produced by alternative splicing Biochemical and Biophysical Research Communications 152 717-723

Shimasaki S, Koga M, Buscaglia ML, Simmons DM, Bicsak TA and Ling N (1989) Follistatin gene expression in the rat ovary and extragonadal tissues Molecular Endocrinology 3 651-659

Shimonaka M, Inouye S, Shimasaki S and Ling N (1991) Follistatin binds to both activin and inhibin through the common $\beta$ subunit Endocrinology 128 $3313-3315$

Sugino K, Kurosawa N, Nakamura T, Takio K, Shimasaki S, Ling N, Titani K and Sugino H (1993) Molecular heterogeneity of follistatin, an activin-binding protein Journal of Biological Chemistry 268 15579-15587

Tsafriri A, Vale W and Hsueh JW (1989) Effect of transforming growth factor and inhibin-related proteins on rat preovulatory Graáfian follicles in vitro Endocrinology 125 1857-1862

Ueno N, Ling N, Ying S-Y, Esch F, Shimasaki S and Guillemin R (1987) Isolation and partial characterization of follistatin: a novel $M_{\mathrm{r}} 35000$ monomeric protein that inhibits the release of follicle stimulating hormone Proceedings of the National Academy of Sciences USA 84 8282-8286

Vale W, Rivier J, Vaughan J, McClintock R, Corrigan A, Woo W, Karr D and Spiess $\mathrm{J}$ (1986) Purification and characterization of an FSH releasing protein from porcine ovarian follicular fluid Nature 321 776-779

Woodruff TK, Lyon RJ, Hansen SE, Rice GC and Mather JP (1990) Inhibin and activin locally regulate rat ovarian folliculogenesis Endocrinology 127 31963205

Xiao S, Findlay JK and Robertson DM (1990) the effect of bovine activin and follicle-stimulating hormone ( $\mathrm{FSH}$ ) suppressing protein/follistatin of FSHinduced differentiation of rat granulosa cells in vitro Molecular and Cellular Endocrinology 69 1-8 